\title{
David Oliver: Making less popular medical jobs more attractive
}

\section{David Oliver consultant in geriatrics and acute general medicine}

Berkshire

\begin{abstract}
Medicine has an unwritten hierarchy of perceived glamour and prestige. This ends up having a real impact on patient care, as it affects who chooses to work in what specialty and which specialties struggle to recruit. Julian Simpson discussed this hierarchy in The BMJ in May, ${ }^{1}$ when he highlighted the NHS's reliance on overseas trained doctors from ethnic minorities for unpopular specialties in deprived or remote UK regions.
\end{abstract}

Many doctors, including me, actively choose disciplines that are generally (if often unfairly) seen as overstretched, less glamorous, struggling to fill all posts, or with lower earning potential. I've never regretted being a geriatrician and general internal medicine physician. This is about tendencies and trends, not absolutes. But what makes a specialty seem more prestigious to potential applicants?

In my experience, terms such as teaching hospital, highly specialised, high tech, interventional, curative, physical health, younger, single organ system, and research active have too often trumped generalist, acute unselected, older, mental health, long term conditions, district hospital, community, and primary. Workforce data, including surveys of recruitment to training posts by specialty, back this perception. ${ }^{2-4}$

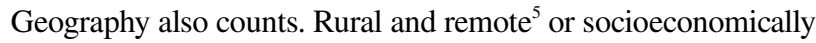
deprived $^{6}$ areas can struggle the hardest to attract and retain medical staff or run viable services.

To study this phenomenon back in 2008, Album and Westin asked medical students and junior and senior doctors to rank 23 medical specialties and 38 medical conditions in order of perceived prestige. ${ }^{7}$ They found high prestige scores for "diseases and specialities associated with technologically sophisticated, immediate and invasive procedures in vital organs located in the upper parts of the body ... especially where the typical patient is young or middle-aged." Low prestige scores were given to "diseases and specialities associated with chronic conditions located in the lower parts of the body or having no specific bodily location, with less visible treatment procedures, and with elderly patients."

Others have described this phenomenon, including Atul Gawande, in writing about doctors' attitudes to geriatric medicine and older patients ${ }^{8}$; Hugh Alberti, in researching negative messages undermining doctors' attitudes to careers in general practice'; and the Royal College of Psychiatrists, on the need to stop "bashing psychiatry."10

We currently find it hardest to recruit and retain doctors in primary or acute care-generalist disciplines with the most onsite working out of hours, the highest degree of risk, and the most patients. Doctors foresee a high potential for overwork, rushed care, disruption to family life, and complaints.

Recruitment gaps create a vicious circle of overwork, making posts harder to fill.

I'd suggest innovative, multipronged approaches to filling posts that are the hardest to recruit for. (This list isn't exhaustive, and I'd welcome more suggestions.) First, let's ensure that, in the hardest to fill specialties and regions, we do more to allow for and support career breaks, less than full time training, and enhanced entitlement to study leave, annual leave, sabbaticals, or opportunities for additional personal development or a portfolio career.

Second, we must train sufficient doctors or allow enough ethical recruitment of overseas medical graduates to supply sufficient practitioners to fill all training, GP, and consultant posts across all disciplines, which will in turn help to staff those harder to fill roles. A slight apparent "oversupply" isn't a disaster, given that one trained medical graduate doesn't equate to one whole time equivalent medical practitioner in the long term. We should also improve doctors' working lives at all stages of their career and keep them motivated in the workforce by improving their logistical and human resource support. ${ }^{11-13}$

Third, recognise the extra stress, responsibility, and night time or evening working in the busiest acute specialties, and increase pay in areas struggling the hardest to recruit or retain doctors. A salary uplift of, say, $15 \%$ above baseline would still be cheaper than employing locums, even if doctors who choose those disciplines haven't picked them for money.

Finally, we all have a responsibility to celebrate the key contribution that the "engine room" specialties make to healthcare-even more so in regions that traditionally find it 
harder to recruit (yet where clinical practice can be hugely rewarding) — and we should resist any disparaging messages that these should be avoided or are a waste of talented doctors' abilities. Good role models and training experiences enhance this.

Right now, I'd say that we have our priorities wrong.

Competing interests: See www.bmj.com/about-bmj/freelance-contributors/davidoliver.

Provenance and peer review: Commissioned; not externally peer reviewed.

Simpson JM. Where are UK trained doctors? The migrant care law and its implications for the NHS-an essay by Julian M Simpson. BMJ 2018;361:k2336. 10.1136/bmj.k2336 29853447

2 Royal College of Physicians. 2016-17 census (UK consultants and higher specialty trainees). 28 June 2017. https://www.rcplondon.ac.uk/projects/outputs/2016-17-censusuk-consultants-and-higher-specialty-trainees.

3 NHS Improvement. Securing a sustainable NHS workforce for the future. 29 June 2017. https://improvement.nhs.uk/news-alerts/securing-sustainable-nhs-workforce-future/.

4 Moberly T. Specialty training vacancies increase by $30 \%$ in a year. BMJ Careers 19 July 2017. http://careers.bmj.com/careers/advice/Specialty_training_vacancies_increase_by_ $30 \% 2525$ in a year.
Oliver D. David Oliver: Challenges for rural hospitals--the same but different. BMJ 2017:357:j1731. 10.1136/bmj.j1731 28400387

6 lacobucci G. Practices in poor areas are more likely to face CQC sanctions. BMJ 2018;360:k680. 10.1136/bmj.k680 29444877

7 Album D, Westin S. Do diseases have a prestige hierarchy? A survey among physicians and medical students. Soc Sci Med 2008;66:182-8. https://www.ncbi.nlm.nih.gov/pubmed/ 17850944. 10.1016/j.socscimed.2007.07.003 17850944

8 Gawande A. The way we age now: medicine has increased the ranks of the elderly. Can it make old age any easier?New Yorker 2007;50-9. https://www.newyorker.com/magazine/ 2007/04/30/the-way-we-age-now. 17508461

9 Alberti H, Banner K, Collingwood H, Merritt K. 'Just a GP': a mixed method study of undermining of general practice as a career choice in the UK. BMJ Open 2017;7:e018520. https://bmjopen.bmj.com/content/7/11/e018520.10.1136/bmjopen-2017-018520 29102997

10 Royal College of Psychiatrists. Royal College calls for an end to "bashing" psychiatrists. 2016. https://www.rcpsych.ac.uk/mediacentre/pressreleases2016/bashcampaign.aspx.

11 Oliver D. David Oliver: Older doctors revisited. BMJ 2017;356:j17. 10.1136/bmj.j17 28087498

12 Royal College of Physicians. Keeping medicine brilliant. 1 Dec 2016. https://www. rcplondon.ac.uk/guidelines-policy/keeping-medicine-brilliant.

13 Health Education England. Enhancing junior doctors' working lives: a progress report. 2016. https://hee.nhs.uk/sites/default/files/documents/Enhancing\%20junior\%20doctors\% 20working\%20lives\%20-\%20a\%20progress\%20report.pdf.

Published by the BMJ Publishing Group Limited. For permission to use (where not already granted under a licence) please go to http://group.bmj.com/group/rights-licensing/ permissions 